\title{
Evaluation of Yield Performance of Chickpea (Cicer arietinum) through Cluster Front Line Demonstration
}

\author{
Hrish Kumar Rachhoya*, Mukesh Sharma and V.K. Saini
}

Krishi Vigyan Kendra (GVM), Sardarshahar, District-Churu -1 (Rajasthan)-334003, India

*Corresponding author

\begin{tabular}{|l|}
\hline Ke y w o r d s \\
Cluster Font Line \\
Demonstration (CFLD), \\
Intervention, Technology, \\
Yield
\end{tabular}

\section{Introduction}

The per capita net availability per day of pulses is still low in India, ranging from 42-47 gram. It is almost stagnating with slight increase in recent years. This is due to the increase in population and almost stagnation in production of pulses. Despite the spiraling prices of pulses, the area and production of
Churu district comes under Desert region of Rajasthan and agriculturally it is very important district. In Churu chickpea cultivation is very common but its productivity is very low. To establish the production potential of crop Cluster Front Line Demonstrations (CFLDs) is an appropriate tool. To increase the production and productivity of gram in the district, Krishi Vigyan Kendra, Gandhi Vidya Mandir, Sardarshahar, Churu-1(Rajasthan) conducted 250 demonstrations on gram during 2015-16 to 2017-18 in four adopted villages. The critical inputs were identified in existing production technology through farmers meeting and group discussions with the farmers. Average yield data of conducted CFLDs revealed that, higher yield $\left(1767 \mathrm{~kg} \mathrm{ha}^{-1}\right)$ was obtained in demo plot over local check (1364 kg ha ${ }^{-1}$ ) and additional yield in demo plot was obtained $403 \mathrm{~kg}$. Percent increase over local check was found $29.54 \%$. Average extension gap, technology gap and technology index were found 402.33, $433.33 \mathrm{kgha}^{-1}$ and $19.69 \%$ respectively. Averages of gross and net returns of demonstration were 29.17 and $42.69 \%$ higher than the farmers' practice respectively. Most important factor $\mathrm{B}: \mathrm{C}$ ratio indicates that whether CFLD technology is profitable or not. B:C ratio was found higher throughout the study and average was (3.10) in demonstration over local check (2.58). Review of data on incidence of disease in crop revealed that, percentage of damaged plant (9.83) was lower in demonstration as compared to (17.10) under farmers' practice. Spraying of propenophos $50 \mathrm{EC}$ at the pod initiation stage reduces pod borer attack, consequently lesser infected pods (2.37) in demo as compared to farmers' practices (7.9). Result suggested economic viability and agronomic feasibility of the CFLD technology for gram cultivation. 
the largest producer, importer and consumer of Pulses in the world. Pulses occupy a prominent place in human nutrition particularly among the lower income groups of people in developing countries like India. Important pulses grown in India are chick pea (Bengal gram), pigeon pea (red gram), lentil (masur), urd bean (black gram), moong bean (green gram), moth bean, pea, grass pea (khesari), cow pea (lobia) and broad bean (faba bean), etc. These grains are relatively inexpensive source of protein in developing countries where protein energy malnutrition is quite common. The protein content in pulse grains generally ranges from $20-25 \%$. Besides protein, pulses are also a good source of dietary fibre, starch, minerals and vitamins. Legumes are typically low in fat, contain no cholesterol, and are high in folate, potassium, iron and magnesium. A good source of protein, legumes can be a healthy substitute for meat, which has more fat and cholesterol. Legumes are included in all 'food baskets' and dietary guidelines. The World Food Programme (WFP) for instance includes 60 grams of pulses in its typical food basket, alongside cereals, oils, sugar and salts. Encouraging awareness of the nutritional value of legumes can helps consumers adopt healthier diets. Legumes are an important component of crop rotations, they require less fertilizer than other crops and they are a low carbon source of protein. They have a direct positive impact on soil quality because they help feed soil microbes, which helps in improving soil health. They have also been shown to produce greater amounts of different amino acids than non-legumes and its plant residues have a different biochemical composition than other crop residues. There are many legumes traditionally used as dal and many of them now being utilized as vegetables. There are several reasons responsible for declining the productivity of pulses is; more focus on cereal crops e.g. wheat \& rice, less investment on irrigation facilities (only $15 \%$ for pulses as against 80 $90 \%$ for wheat/ rice), technological absence to minimize disease, insect and weed infestation, that caused substantial damage $(30 \%)$ in standing crops, green revolution just by passed the pulses and hence the use of HYVs for pulses was never encouraged, lack of quality seed of improved varieties, cultivation on less fertile soil, rainfed and marginal lands, imbalance use of nutrient, lack of integration of nutrient supply sources and adverse impact of weather aberrations on crops.

In general the productivity of gram crop in Churu is low because of least technological backup, small and marginal land holdings and poor adoption of improved package of practices. Therefore, efforts have been made through Front Line Demonstrations (FLDs) to introduce innovative package of practices of gram with a view to increase its productivity in the district. So, the present investigation has been undertaken with following objectives.

To evaluate the impact of Cluster Front Line Demonstration on yield enhancement of gram.

To investigate the impact of Cluster Front Line Demonstration on technology adoption.

To find out the role of technology in minimizing the disease and insect infestation.

\section{Materials and Methods}

The present study was carried out by Krishi Vigyan Kendra and 250 demonstrations were conducted in its adopted village's viz. Dhingli, Sulakiniya Chota, Sulakiniya Bada, Bhadasar, Swai Delna, Udwala, Dhani Suhana and Mitasar of Churu district of Rajasthan in Rabi season of 2015-16, 2016-17 and 2017-18 on the selected farmers' fields. Each demo was conducted in 0.4 ha (one acre) and thus, 250 demonstrations were conducted 2015-16 to 2017-18 year. For the adoption of village PRA 
technique and for the selection of farmers the purposive sampling design from frequently organized group meetings was exercised in each village. Before conducting CFLDs, a list of sample farmers was prepared. Package of practices (POP) oriented training to be imparted to the selected farmers (Venkattakumar et al., 2010). During meeting, receptive and innovative farmers were selected for technological intervention. Improved technology released from SKRAU Bikaner was adopted, which was comprised of soil test based fertilizers tailoring (20:32:0:40 $\mathrm{kg}$ NPKS ha ${ }^{-1}$ ), seed treatment (Carbendazim $2 \mathrm{~g} \mathrm{~kg}^{-1}$ seed followed by Bradyrhizobium japonicum and PSB culture @ $600 \mathrm{~g} \mathrm{ha}^{-1}$ seed), soils treatment (Trichoderma harzyanum culture @ $05 \mathrm{~kg} \mathrm{ha}^{-1}$ ), Disease resistant variety GNG-1581, Seed (@60 kg $\mathrm{ha}^{-1}$ ), sowing time (first fort night of October), sowing by Seed cum fertilizer drill, sowing distance ( $30 \mathrm{~cm} \mathrm{R}$ to $\mathrm{R}$ ), weed management, harvesting (between last week of March to first week of April).In general the soil in which FLDs were conducted having $\mathrm{PH}$ range of 7.32-8.12, EC $0.4-0.7 \mathrm{dSm}^{-1}$, organic carbon, phosphorus and potassium whose ranges were $0.23-0.33,45-51$ and $>280 \mathrm{~kg}$ hal respectively. Soils come under arid soil order and defined as medium sandy soils.

The performance of demonstrated technology was compared with farmers practice in the same villages. Farmers' practice included imbalance use of fertilizers i.e. 18:46:0:0 kg NPKS ha ${ }^{-1}$, higher seed rate $\left(80-100 \mathrm{~kg} \mathrm{ha}^{-1}\right)$ and indiscriminate use of pesticides. The differences in between demonstrated technology and existing farmers' practices (local check) are mentioned in table 1.

To study the yield attributes, 25 plants were selected by randomly placing of quadrate at five places in demo plots as well as in FPs plots and five plants selected from each quadrate. Yield data from demonstration and
FPs' were collected after harvesting the crop. For the recording of seed index 100 seeds were taken and weighed. Economical assessment was done as per prevailing market prices.

\section{Results and Discussion}

Data were collected from both demos as well as farmers' practice plots and analyzed for the yield gap, yield index (Samui et al., 2003).

\section{Yield}

Implementation of improved production technology remarkably increased the yield (27.00-31.07 \%) over farmers' practice during the three year of demonstration. The average yield under recommended practice was achieved $1721 \mathrm{~kg} \mathrm{ha}^{-1}$ as compared to the farmers' practice $1328 \mathrm{~kg} \mathrm{ha}^{-1}$ which was $29.63 \%$ higher (Table 2). Although yield obtained under demo plots was lower than the potential yield of variety. It may be due to cumulative effect of several biotic and a biotic factors in micro climatic conditions that varying year to year.

Yield enhancement under recommended practice might be due to balance nutrition as per soil test value, integrated approach, involving fertilizers and bio-fertilizers which play a vital role in making availability of plant nutrients. Similar results were observed by Tomar et al., (2003), Tiwari and Saxena (2001) and Tiwari et al., (2003).

Data presented in table 2 revealed that demonstrated technology had impact over farmers' practices. It might be due to cumulative effect of yield attributes and seed index. The yield increased in demonstrated field due to technological intervention may happen in other similar situation. The results are in agreement with the findings as reported by Tomar et al., (2003). 
Table.1 Comparison between technological intervention and local check under CFLDs on gram

\begin{tabular}{|c|c|c|c|c|}
\hline $\begin{array}{l}\text { S. } \\
\text { No }\end{array}$ & Particulars & $\begin{array}{l}\text { Technological } \\
\text { Intervention } \\
\text { (Demonstration) }\end{array}$ & $\begin{array}{l}\text { Farmers Practice } \\
\text { (Local Check) }\end{array}$ & $\begin{array}{l}\text { Technological } \\
\text { Gap }\end{array}$ \\
\hline 1 & $\begin{array}{l}\text { Farming } \\
\text { situation }\end{array}$ & Irrigated & Irrigated & No gap \\
\hline 2 & Variety & GNG-1581 & Unidentified & $\begin{array}{l}\text { Full gap (100 } \\
\%)\end{array}$ \\
\hline 3 & $\begin{array}{l}\text { Land } \\
\text { preparation }\end{array}$ & $\begin{array}{l}\text { Summer deep ploughing } \\
\text { followed by rotavator }\end{array}$ & $\begin{array}{l}\text { Summer deep } \\
\text { ploughing followed by } \\
\text { rotavator }\end{array}$ & No gap \\
\hline 4 & Time of sowing & First forth night of October & $\begin{array}{l}\text { First forth night of } \\
\text { October }\end{array}$ & No gap \\
\hline 5 & Seed treatment & $\begin{array}{l}\text { Carbendazim } 2 \mathrm{gkg}^{-1} \text { seed }+ \\
\text { Bio-fertilizers }\end{array}$ & No seed treatment & $\begin{array}{l}\text { Full gap (100 } \\
\%)\end{array}$ \\
\hline 6 & Seed rate & $60 \mathrm{~kg} \mathrm{ha}^{-1}$ & $80-100 \mathrm{~kg} \mathrm{ha}^{-1}$ & $\begin{array}{l}15-30 \% \text { more } \\
\text { than } \\
\text { recommendation }\end{array}$ \\
\hline 7 & $\begin{array}{l}\text { Method of } \\
\text { sowing }\end{array}$ & Line sowing & Broadcasting sowing & No gap \\
\hline 8 & $\begin{array}{l}\text { Nutrients } \\
\text { application }\end{array}$ & 20:32:20:40 kg NPKS ha-1 & $\begin{array}{l}\text { 16:46:0:0 kg NPKS } \\
\text { ha }^{-1}\end{array}$ & $\begin{array}{l}\text { Not as per } \\
\text { recommendation }\end{array}$ \\
\hline 9 & $\begin{array}{l}\text { Weed } \\
\text { management }\end{array}$ & Manual weeding & Manual weeding & No gap \\
\hline 10 & $\begin{array}{l}\text { Pod borer } \\
\text { control }\end{array}$ & $\begin{array}{l}\text { Applied Quinolphos } 25 \mathrm{EC} \\
\text { @ } 2.0 \mathrm{ml} / \text { liter Water }\end{array}$ & $\begin{array}{l}\text { Use of indiscriminate } \\
\text { and non recommended } \\
\text { insecticides }\end{array}$ & $\begin{array}{l}\text { Full gap (100 } \\
\%)\end{array}$ \\
\hline
\end{tabular}

Table.2 Performance of technological intervention (CFLDs) on yield and yield attributes of gram

\begin{tabular}{|c|c|c|c|c|c|c|c|c|c|}
\hline \multirow[t]{2}{*}{ Year } & \multirow[t]{2}{*}{ Variety } & \multirow[t]{2}{*}{$\begin{array}{c}\text { Yield } \\
\text { Potential } \\
\left(\mathrm{Kg} \mathrm{ha}^{-1}\right)\end{array}$} & \multicolumn{2}{|c|}{$\begin{array}{c}\text { Plant } \\
\text { Population } \\
\text { (No/M2) }\end{array}$} & \multicolumn{2}{|c|}{$\begin{array}{l}\text { Seed yield } \\
\left(\mathrm{Kgha}^{-1}\right)\end{array}$} & \multicolumn{2}{|c|}{$\begin{array}{l}\text { Seed index } \\
\text { (g/100 seeds) }\end{array}$} & \multirow{2}{*}{$\begin{array}{c}\% \\
\text { increase } \\
\text { over } \\
\text { control } \\
\text { (FP) }\end{array}$} \\
\hline & & & $\mathrm{RP}$ & FP & $\mathrm{RP}$ & FP & $\mathrm{RP}$ & FP & \\
\hline 2015-16 & $\begin{array}{c}\text { GNG- } \\
1581\end{array}$ & 2300 & 44 & 38 & 1710 & 1307 & 16.3 & 14.7 & 30.83 \\
\hline 2016-17 & $\begin{array}{c}\text { GNG- } \\
1581\end{array}$ & 2300 & 47 & 39 & 1742 & 1329 & 16.0 & 15.9 & 31.07 \\
\hline 2017-18 & $\begin{array}{c}\text { GNG- } \\
1581\end{array}$ & 2300 & 48 & 40 & 1712 & 1348 & 16.8 & 15.4 & 27.00 \\
\hline Average & - & 2300 & 46.33 & 39.0 & 1721 & 1328 & 16.36 & 15.33 & 29.63 \\
\hline
\end{tabular}

RP: Recommended Practice

FP: Farmers Practice 
Table.3 Economical comparison between recommended practice and farmers practice

\begin{tabular}{|c|c|c|c|c|c|c|c|c|}
\hline Year & \multicolumn{2}{|c|}{ Gross cost $\left(\right.$ Rs.ha $\left.^{-1}\right)$} & \multicolumn{2}{|c|}{ Gross return $($ Rs. ha } & Net return(Rs. ha & \multicolumn{2}{|c|}{ B: C Ratio } \\
\hline & RP & FP & RP & FP & RP & FP & RP & FP \\
\hline $\mathbf{2 0 1 5 - 1 6}$ & 19256 & 17654 & 68400 & 52280 & 49144 & 34626 & 3.55 & 2.96 \\
\hline $\mathbf{2 0 1 6 - 1 7}$ & 22600 & 18890 & 78384 & 49679 & 55784 & 30789 & 3.46 & 2.62 \\
\hline $\mathbf{2 0 1 7 - 1 8}$ & 23425 & 19580 & 70244 & 46976 & 46819 & 27396 & 2.99 & 2.39 \\
\hline Average & 21760 & 18708 & 72343 & 49645 & 50582 & 30937 & 3.33 & 2.65 \\
\hline
\end{tabular}

Table.4 Impact of technological intervention on pest infestation

\begin{tabular}{|c|c|c|c|c|c|c|c|}
\hline \multirow{2}{*}{ Year } & \multicolumn{2}{|c|}{ Disease affected plants M-2 } & \multicolumn{2}{|c|}{ Damage \% } & \multicolumn{2}{|c|}{ Infected pods (No/plant) } \\
& RP & FP & RP & FP & RP & FP \\
\hline $\mathbf{2 0 1 5 - 1 6}$ & 4.2 & 6.3 & 9.33 & 16.15 & 1.2 & 7.8 \\
\hline $\mathbf{2 0 1 6 - 1 7}$ & 4.6 & 7.1 & 9.58 & 17.31 & 3.3 & 9.2 \\
\hline $\mathbf{2 0 1 7 - 1 8}$ & 5.1 & 7.5 & 10.58 & 17.85 & 2.6 & 6.7 \\
\hline Average & 4.63 & 6.97 & 9.83 & 17.10 & 2.37 & 7.9 \\
\hline
\end{tabular}

Table.5 Impact of CFLDs on Extension, technology gap and yield index

\begin{tabular}{|c|c|c|c|}
\hline Year & Extension gap $\left(\mathrm{kg} \mathrm{ha}^{-1}\right)$ & Technology gap $\left(\mathrm{kg} \mathrm{ha}^{-1}\right)$ & Technology index (\%) \\
\hline $\mathbf{2 0 1 5}-16$ & 403 & 590 & 25.65 \\
\hline $\mathbf{2 0 1 6 - 1 7}$ & 413 & 558 & 24.26 \\
\hline $\mathbf{2 0 1 7}-18$ & 364 & 588 & 25.56 \\
\hline Average & 393.33 & 579 & 25.17 \\
\hline
\end{tabular}

\section{Economical assessment}

The cost of cultivation in demonstration was comparatively higher (Rs. 19256-23425) as compared to farmers' practice (Rs. 17654 19580) because of additional input applied in demonstration. The gross return (Rs.49645) and net returns (Rs.30937) in farmer practice were lower than the gross return (Rs. 72343) and net returns (Rs. 50582) of demonstration. Average of gross and net returns of demonstration was $45.72 \%$ and $63.50 \%$ higher than that of farmers' practice respectively. It showed that the adoption of demonstrated technology by the farmers would be economically gainful proposition.

The $\mathrm{B}$ : $\mathrm{C}$ ratio exhibited the same trend as in gross and net returns which was found 2.99 3.55 in demonstration and $2.39-2.96$ in farmers' practice (Table 3). Year to year ups and downs in cost of cultivation, which consequently reflected the benefits were on account of variability in cost of inputs and outputs. Results suggested economic viability and agronomic feasibility of the technology for gram cultivation. These results are in conformity of the results as reported by Deshmukh et al., (2010).

\section{Disease incidence}

Data recorded on plants infested with wilt (Fusarium wilt) caused by Fusarium oxysporum f.sp. ciceris revealed that, incidence of disease was lower in 
demonstration plot as compared to farmers' practice. It was observed that on an average only 4.63 plants M-2 showed wilting symptoms in demonstrations compared to 6.97 (average) plants $\mathrm{M}-2$ in farmers' practice. Data presented in Table 4 reflected that the percentage of damaged plant (9.83) was lower in demonstration as compared to farmers' practice (17.10). This could be ascribed due to seed treatment. The findings are in line with the results reported by Chand and Khirbat (2009) and Nene et al., (2011).

\section{Insect infestation}

During the study, data as recorded (Table 4) on infestation of pod borer (Helicoverpa armigera) caused premature dry and shading of pods. Spraying of quinalphos 25 EC @ 2.0 $\mathrm{ml} /$ liter Water at the time of pod initiation caused lesser pods infected (2.37) as compared to farmers' practices (7.9). Similar results quoted by Hossain et al., (2010).

\section{Extension gap, technology gap and yield index}

Data presented in Table 5 showed the variation in extension gap and it varied from $364-413 \mathrm{~kg} \mathrm{ha}^{-1}$ with its averaged $393.33 \mathrm{~kg}$ $\mathrm{ha}^{-1}$. Variations in technology gap $(558-590$ $\mathrm{kg} \mathrm{ha}^{-1}$ ) reflected the impact of recommended technology used in front line demonstrations in subsequent years. Fluctuations in technology gap as observed may be due to several biotic and abiotic factors. These results are in close conformity with the findings of Mitra and Samajdar (2010).

Yield index showed the feasibility of the evolved technology at the farmers' fields. Lower value of yield index meant more feasibility of disseminated technology (inverse relations). Variations in technology index during the CFLDs were found 24.26 $25.65 \%$ however; its average of three year was $25.17 \%$ (Table 5). Variations in yield index may be due to variations in soil fertility, environmental hazards and infestation of pest. The reduction in yield index (24.26) is good indicator of increased feasibility of demonstrated technology in these demonstrations and it can be gainful proposition for the farmers of the district and region as well. The results corroborated with the findings reported by Sagar and Chandra (2004).

\section{References}

Chand, H. and Khirbat, S.K. (2009). Chickpea wilt and its management - a review. Agric. Rev., 30 (1):1-12.

Deshmukh, K. K., Saraiya, A.B. and Dubey, D.P. (2010). Effect of integrated nutrient management on productivity trends, economics and soil fertility in soybean-chickpea cropping system. JNKVV Res. J. 39 (2): 29-32.

Hossain Altaf, Haque Azizul, Ahmad Masum and Prodhan M.Z.H. (2010). Development of an integrated management approach for pod borer, Helicoverpa armigera (Hubner) on chickpea. Bangladesh J. Agril. Res. 35(2): 201-206.

Mitra Biplab, and Samajdar, T. (2010). Yield gap analysis of rapeseed- mustard through FLD. Agricultural Extension Review, April-June., 16-17.

Nene, Y.L., Mengistu A., Sinclair, J.B. and Royse, D.J. (2011). An annotated bibliography of chickpea diseases, Information bulletin, No.1. PP 1-53.

Sagar, R., L. and Ganesh, Chandra (2004). Front line demonstration on seasame in West Bengal. Agricultural Extension Review, 16 (2): 7-10.

Samui, S., K. Maitra, S., Roy, D., K. Mandal, A., K. and Saha, D. (2003). Evaluation of front line demonstration on ground nut. Journal of the Indian Society 
Coastal Agricultural Research, 18 (2): 180-183.

Tiwari, K., B. and Saxena, A. (2001). Economic analysis of FLD of oil seed in Chhindwara. Bhartiya Krishi Anusandhan Patrika, 16 (3 \& 4): 185189.

Tiwari, R.B., Singh, Vinay and Parihar, Pushapa. (2003). Role of FLD in transfer of gram production technology. Maharashtra J. Ext. Edu., 22 (1): 19.

Tomer, L.S., Sharma, B.P. and Joshi, K. (2003). Impact of front line demonstration of soybean in transfer of improved technology. Journal of Ext.Edu. 22 (1):139.

Tomer, L.S., Sharma, B.P. and Joshi, K. (2003). Study on yield gap and adoption level of potato production technology in grid region. Maharashtra J. Ext. Edu., 22 (1): $15-18$.

Venkattakumar, R., Ramanarao, S.V., Padmaiah, M. and Madhuri, P. (2010). Production constraints and information needs growers in Andhra Pradesh. Agri. Extn. Review, April- June: Pp. 21-24.

\section{How to cite this article:}

Hrish Kumar Rachhoya, Mukesh Sharma and Saini, V.K. 2018. Evaluation of Yield Performance of Chickpea (Cicer arietinum) through Cluster Front Line Demonstration. Int.J.Curr.Microbiol.App.Sci. 7(05): 2465-2471. doi: https://doi.org/10.20546/ijcmas.2018.705.282 